\title{
The evaluation of musculoskeletal system problems and related factors in physiotherapists working in Diyarbakır province
}

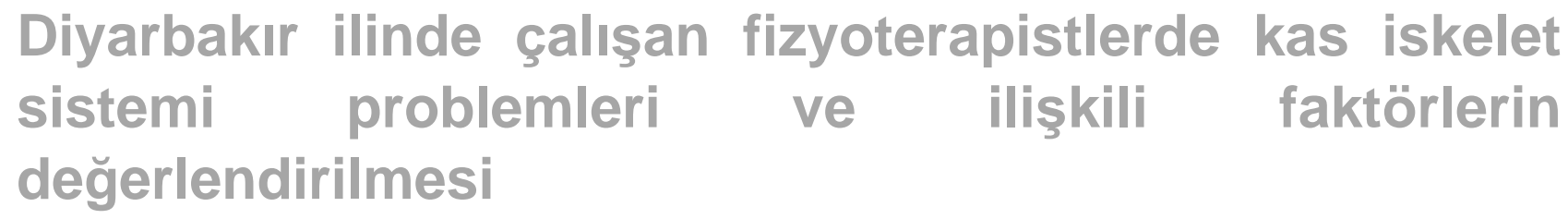

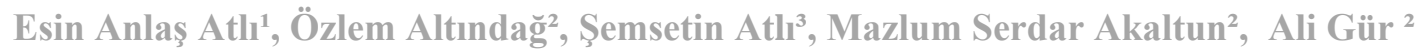

${ }^{1}$ Gaziantep University, Health Sciences Faculty, Physical Therapy and Rehabilitation Department, Gaziantep, Turkey
${ }^{2}$ Gaziantep University, Faculty of Medicine, Department of Physical Medicine and Rehabilitaton, Gaziantep, Turkey

${ }^{3}$ Gazi Yasargil Research Hospital, Neurology Department, Diyarbakır, Turkey

Corresponding author: Mazlum Serdar Akaltun, MD, Gaziantep University, Faculty of Medicine, Department of Physical Medicine and Rehabilitaton, Gaziantep, Turkey

E-mail: mazlum akaltun@hotmail.com

Received/Accepted: January 14, 2019 /August 16, 2020

Conflict of interest: There is not a conflict of interest.

\section{SUMMARY}

Objective: In this study, it is aimed to investigate the musculoskeletal disorders of physiotherapists working in Diyarbakır and to determine the relationship between these problems and age, gender, working year, working hours, weekly working day and whether to exercise or not. Method: This study was carried out with the participation of 99 physiotherapists working in various regions in Diyarbakır. NORDIC survey was used in the study. Participants were questioned for the presence of pain in the last twelve months for each part, the presence of pain in the last seven days, and the effect of pain on daily life. The datawas obtained by distribution and collection of the survey.

Results: Although $83.2 \%$ of theparticipants thought that their complaints such as pain, discomfort, and numbness were related to the work they were doing, $16.2 \%$ of them didn't associate their complaints with their work. Based on the proportion of physiotherapists with and without pain according to body regions in the last 12 months, back pain was found in the $65.7 \%$ of the participants with the highest percentage. 59.6\% low back pain, $57.6 \%$ neck pain, $53.5 \%$ hand -wrist pain and $52.5 \%$ shoulder pain were found in the participants respectively.

Conclusions: This study is a preliminary study for a larger participatory study in which the risk factors of musculoskeletal disorders can also be determined. The study shows that physiotherapists form a risk group in terms of musculoskeletal disorders. It has been determined that musculoskeletal problems in physiotherapists are related to BMI, gender, and doing or not doing exercise.

Keywords: Exercise, pain, physiotherapists, musculoskeletal problems, Nordic survey.
Esin Anlaş Atlı
(D) Özlem Altındağ
(iD) Şemsetin Atlı
(D) Mazlum Serdar Akaltun
Ali Gür

ORCID IDs of the authors: E.A.A. 0000-0002-7993-8602 Ö.A. 0000-0003-1119-2987 Ş.A. $0000-0003-3045-5789$ M.S.A. 0000-0002-9666-9483 A.G. 0000-0001-9680-6268 
Amaç: Bu çalışmada Diyarbakır ilinde çalışan fizyoterapistlerin kas iskelet sistemi problemlerinin araştırılması ve bu problemlerin yaş, cinsiyet, çalışma yılı, çalışma saati, haftalık çalışma günü ve egzersiz yapıp yapmama ile ilişkisinin belirlenmesi amaçlanmıştır.

Yöntem: Bu çalışmaya Diyarbakır ilinde çeşitli merkezlerde çalışan 99 fizyoterapist katılmıştır. Çalışmada 'Genişletilmiş Nordic Kas İskelet Sistemi anketi' kullanılmıştır. Ankette vücut boyun, omuz, dirsek, el/ el bileği, sırt, bel, kalça/uyluk, diz, ayak/ ayak bileği şeklinde dokuz bölgeye ayrılmıştır. Katılımcılar her bölge için son on iki ayda ağrının varlığı, son yedi günde ağrının varlığı ve ağrıların günlük yaşamı etkilemesi açısından sorgulanmıştır. Fizyoterapistlere anketin dağıtılması ve toplanması şeklinde veriler elde edilmiştir.

Bulgular: Katılımcıların \%83,2 si vücutlarındaki ağrı, sızı, uyuşma gibi şikayetlerin yaptıkları işle ilgili olduğunu düşünürken, $\% 16,2$ si şikayetlerini iş ile ilişkilendirmemişlerdir. Son 12 ayda vücut bölgelerine göre ağrısı olan ve olmayan fizyoterapistlerin oranlarına bakıldığında katılımcılarda en fazla $\% 65,7$ oranla sırt ağrısı daha sonra $\% 59,6$ bel ağrıs1, $\% 57,6$ boyun ağrıs1, $\% 53,5$ el/ el bileği ağrıs1, $\% 52,5$ omuz ağrıs1 görüldüğü saptanmıştır. Son 12 ay içinde dirsek ağrısı çeken katılımcıların günlük çalışma süre ortalamaları daha yüksek bulunmuştur $(\mathrm{p}<0,05)$. Son 12 ay içinde bel ağrısı çeken katılımcıların beden kitle indeksi ortalamaları daha yüksek bulunmuştur $(\mathrm{p}<0,05)$. Son 12 ay içinde dirsek ağrısı çeken katılımcıların haftada çalıştıkları gün sayısı ortalamaları daha yükssek bulunmuştur $(p<0,05)$. Son 12 ay içinde, kadınlarda omuz bölgesinde hissedilen ağrının erkeklere oranla anlamlı olarak daha yüksek, erkeklerde ise ayak/ ayak bileği bölgesinde hissedilen ağrının kadınlara oranla anlamlı olarak daha yüksek olduğu bulunmuştur $(\mathrm{p}<0,05)$. Son 12 ay içinde, egzersiz yapmayan katılımcıların diz ve boyun bölgesinde ağrı yaşama oranı anlamlı olarak daha yüksek bulunmuştur $(\mathrm{p}<0,05)$. Son 12 ayda; boyun, omuz, dirsek, el bileği, sırt, bel, kalça/uyluk, diz ve ayak bölgelerinde ağrı hissetme ve hissetmeme durumlarının yaș ve çalıșma yılı ile ilișkili olmadığı saptanmıștır

Sonuç: Bu çalışma kas iskelet sisteminin risk faktörlerinin de belirlenebileceği daha geniş katılımlı bir çalışma için ön çalışma niteliğindedir. Çalışma fizyoterapistlerin kas iskelet sistemi problemleri açısından bir risk grubu oluşturduğunu göstermiştir. Fizyoterapistlerde görülen kas iskelet sistemi problemlerinin beden kitle indeksi, cinsiyet, egzersiz alıșkanlığı ile ilișkili olduğu belirlenmiștir.

Anahtar sözcükler: Fizyoterapist, kas iskelet sistemi problemleri, Nordic anket

\section{INTRODUCTION}

Musculoskeletal system problems (MSP) are seen quite frequently and are in a very close relationship with one's work ${ }^{1}$.In 2001, the National Institute for Occupational Safety and Health (NIOSH) defined $65 \%$ of work-related diseases as $\mathrm{MSP}^{2}$.Physical, psychosocial and personal factors play a role in the MSP etiology. The main physical factors are bad posture, repetitive and challenging movements, movement with wrong body mechanics, vibration and static positions. The frequent repetition of physical body activities such as bending, straightening, gripping, reaching, and also fast and physically demanding movements are harmful to the employees ${ }^{2,3}$.The most commonMSP in individuals working under insufficient ergonomic conditions in the workplace are waist, neck and upper extremity problems ${ }^{4}$.

The MSP are more common in some job classes, but the most common in healthcare workers. Physiotherapists, ergotherapists, rehabilitation nurses and assistant personnel who work with patients with neurological and orthopedic problems are more sensitive in terms of musculoskeletal system problems ${ }^{5}$.
There are many studies aiming to conduct MSP research in healthcare workers, and it seems that there are not enough studies carried out on physiotherapists on this subject.The aim of this study is to determine the MSP in physiotherapists working in Diyarbakır and to investigate the related factors.

\section{MATERIAL AND METHODS}

For our study, between the dates of September 2017- November 2017, 104 physiotherapists working in different regions in Diyarbakır for at least 1 year were interviewed, 5 people were excluded because they did not meet the inclusion criteria, and 99 volunteer physiotherapists were included in the study, 27 of whom were women and 72 were men. All participants in the study were informed about the study and volunteer consent form was filledfor each.Inclusion criteria were determined as working in Diyarbakır, working as a physiotherapist for at least 1 year and volunteering for participation in the study.Those with a working period of less than 1 year, pregnants and new mothers, and those with a history of trauma were excluded from the study.

Age, BMI, working year, number of working days per week, daily working hours of all participants were questioned and recorded in the sociodemographic data form.MSP of the participants were evaluated by usingNordic 
survey.Nordic survey is a survey frequently used for determining MSP ${ }^{6}$.In the Nordic survey, the body is examined in nine regions: neck, hand / wrist, elbow, shoulder, back, waist, hip, knee, foot / ankle.For each region, they were questioned about whether there were pains in the last 12 months and in the last 7 days and the effect of these pains on daily life. Even if there were no complaints, these questions were asked to be answered as yes or no.

\section{Statistical Analysis}

In accordance with the aim of the study,MannWhitney U test was used to analyse the relationship between the painful areas of the participants such as neck, shoulder, elbow, hand / wrist, back, waist, hip / thigh, knee and foot / ankle and working year, daily working hours, BMI, age and number of working days per week.Chi-square analysis was performed to analyse the relationship between the painful regions of the participants such as neck, shoulder, elbow, hand / wrist, back, waist, hip / thigh, knee and foot / ankle, and gender and doing exercise or not.Data was analysed by using SPSS 25.0 statistical software. Analysis results were handled at 95\% confidence level and $\mathrm{p}<0.05$ values were considered statistically significant.

\section{RESULTS}

99 volunteers (27 women (27.3\%), 72 men / $72.7 \%$ ) were included in the study. The average age of the physiotherapists who participated in the study was $28.43 \pm 3.74$. The average working year of the participants was $4.71 \pm 3.61$.

$59(59.6 \%)$ of the participants work in the hospital, $40(40.4 \%)$ of them work in special education and rehabilitation centers. While the number of participants who regularly exercised was 26 (26.3\%), the number of participants who did not exercise regularly was 73 (73.7\%). Considering the relationship between pain and work, 83 of the participants $(83.8 \%)$ associated their pain with work.

When we look at the proportion of physiotherapists with and without pain according to their body regions in the last 12 months, the back pain was observed with a maximum rate of $65.7 \%$ in the participants.Then, 59.6\% low back pain, 57.6\% neck pain, $53.5 \%$ hand / wrist pain, $52.5 \%$ shoulder pain, $35.4 \%$ knee pain, $13.1 \%$ elbow pain, $9.1 \%$ hip pain and $6.1 \%$ foot / ankle pain were observed (Table 1).

Table 1: Distribution of physiotherapists with and without pain according to body regions in the last 12 months

\begin{tabular}{|l|c|c|}
\hline The Last 12 months & Frequency & Percentage \\
\hline Neck Yes & 57 & 57,6 \\
No & 42 & 42,4 \\
\hline Shoulder Yes & 52 & 52,5 \\
No Yes & 47 & 47,5 \\
\hline Elbow Yes & 13 & 13,1 \\
No & 86 & 86,9 \\
\hline Wrist Yes & 53 & 53,5 \\
No Yes & 46 & 46,5 \\
& & \\
\hline Back Nos & 65 & 65,7 \\
No back Yes & 34 & 35,3 \\
\hline No Yes No & 59 & 59,6 \\
Hip Yo & 40 & 40,4 \\
\hline Knee & 9 & 9,1 \\
No Yos & 90 & 90,9 \\
\hline Foot Yes & 35 & 35,4 \\
No & 64 & 64,6 \\
\hline Total & 6 & 6,1 \\
\hline
\end{tabular}


When looking at the distribution of pain according to the body regions in the last 7 days, it was determined that the participants had low back pain with a rate of $41.4 \%$, which was the highest.Then
$40.4 \%$ back pain, $34.3 \%$ neck pain, $32.3 \%$ shoulder pain, $22.2 \%$ hand / wrist pain, $25.3 \%$ knee pain, $6.1 \%$ hip pain, $5 \%, 1$ foot / ankle pain and 3\% elbow pain were observed (Table 2).

Table 2: Distribution of physiotherapists with and without pain according to body regions in the last 7 days

\begin{tabular}{|l|c|c|}
\hline The Last 7 days & Frequency & Percentage \\
\hline Neck Yes & 34 & 34,3 \\
No & 65 & 65,7 \\
\hline Shoulder Yes & 32 & 32,3 \\
No Yes & 67 & 67,7 \\
\hline Elbow Yes & 3 & 3,0 \\
No Yes & 96 & 97,0 \\
\hline Wrist Yes & 22 & 22,2 \\
No Yes & 77 & 77,8 \\
\hline Back No & 40 & 40,4 \\
Low back & 59 & 59,6 \\
No Yes & 41 & 41,4 \\
\hline Hip Yes No & 58 & 58,6 \\
\hline Knee Nos & 6 & 6,1 \\
No & 93 & 93,9 \\
\hline Foot Yes & 25 & 25,3 \\
No & 74 & 74,7 \\
\hline Total & 5 & 5,1 \\
\hline
\end{tabular}

When we questioned whether the complaints such as pain, ache and numbness in the body regions in the last 12 months affect work and daily life activities, it was found that the back pain affected the most with the rate of 34.3\%.Laterit was determined that $33.3 \%$ low back pain, $27.3 \%$ shoulder pain, $24.2 \%$ neck pain, $18.2 \%$ knee pain, $17.2 \%$ hand / wrist pain, $6.1 \%$ foot / ankle and elbow pain, $\% 5.1$ hip pain affected work and daily life.

No relationship was found between the pain state of the participants who felt pain in the last 12 months and the working year and age (p> 0.05 ). While shoulder pain was more common in women, foot / ankle pain was more common in men ( $\mathrm{p}<0.05)$.Participants who had low back pain in the last 12 months were found to have a higher rate than those without BMI $(p<0.05)$. When the relationship between daily working hours and pain state was examined, it was found that those with elbow pain had higher working hours than those without elbow pain $(p<0.05)$.No relationship was found between pain in other regions and working hours ( $p>0.05)$. Neck and knee pain were less common in participants who did exercise than those who did not do exercise $(\mathrm{p}<0.05)$.

It was found thatthe average age of the participants who felt elbow pain in the last 7 days was lower (p $<0.05$ ).In the last 7 days, the rate of women's experiencing pain in the neck, elbow and wrist regions was higher $(\mathrm{p}<0.05)$. There was no relationship between the painful regions in the last 7 days and the working year( $p>0.05)$.The averages of daily working hoursof the participants who felt pain in the foot / ankle region in the last 7 days were higher(p <0.05). There was no statistically significant difference between the BMI averages of the participants who felt pain and did not feel pain in the last 7 days ( $p>0.05$ ). There was no statistically significant difference between the average number of working days per week of participants who felt and did not feel pain in the last 7 days ( $p>0.05$ ).In the last 7 days, the rate of experiencing pain in the neck region of the participants who did not exercise was higher ( $\mathrm{p}$ $<0.05)$. 
No relationship was found between painful regions and the working year in terms ofaffecting work and daily life ( $p>0.05$ ).Participants who felt pain in the elbow and hip / thigh regions in terms of affecting work and daily life were found to have higher averages of daily working hours (p $<0.05$ ).Participants who felt painaffecting work and daily lifein the shoulder and waist regions were found to have higher averages of BMI ( $p<0.05)$. There was no relationship between pain and age in terms of affecting work and daily life ( $p>0.05$ ). The average number of working days per week of participants who stated that they felt pain in the elbow region affecting work and daily life was higher $(\mathrm{p}<0.05)$. The rate of experiencing pain affecting work and daily life was higher in the neck region of women $(\mathrm{p}<0.05)$.The rate of experiencing pain affecting work and daily life in the shoulder region of the participants who stated that they did not exercise was found to be higher ( $p$ $<0.05$ ).

\section{DISCUSSION}

There are many studies to investigate musculoskeletal problems in health care workers. However, there are not enough studies aboutMSP in physiotherapists. In the study conducted by Dıraçoğlu, doctors, dentists, nurses and caregivers were evaluated and the rate of those with pain in at least one body region was found to be $90.3 \%$. When the distribution of pain among healthcare workers was examined, it was found that low back pain was most common in doctors, nurses and caregivers, and neck pain was most common in dentists.It was reported that low back pain was significantly higher in women than in men ${ }^{7}$.

When we look at the studies among physiotherapists, the frequency of work-related injuries was found to be $71.6 \%$ in the last 12 months in the study conducted by Nordin et al. on 106 physiotherapists. It has been reported that this rate is higher in women than in men $(73 \%)^{8}$.In our study, there were relatively more complaints in the neck, shoulders, elbows, wrists, back, knees regions in women, but it was found to be significantly higher in the shoulder region than men.It was observed that there were relatively more complaints in the waist, hip, foot / ankle regions in men, but it was found to be significantly higher in the foot / ankle region.

In the study conducted by Tekeli, it was determined that $59 \%$ of physiotherapists working with children and $69 \%$ of physiotherapists working with adults experienced more than one musculoskeletal system problems. When analysed regionally, it was found that the physiotherapists working with adults had problems in the waist $(51 \%)$, neck $(48 \%)$, wrist $(38 \%)$ and back $(20 \%)$ most.It was found that the physiotherapists working with children had problems in the waist (49\%), neck (32), wrist $(26 \%)$, back $(20 \%)$ most ${ }^{9}$.In our study, the institutions where physiotherapists work were determined, but the study areas were not determined with certain limits.However, the most common regions where musculoskeletal system problems occured in the last twelve months were back (65.7\%), waist (59.6\%), neck (57.6\%), wrist $(53.5 \%)$.Both studies are parallel in terms of the regions where the musculoskeletal system problems occur most frequently.

In a study conducted by Salik et al. on physiotherapists working in Izmir, it was found that $85 \%$ of physiotherapists had one or more musculoskeletal problems. These problems were mostly seen in the waist (26\%), wrist (18\%), shoulder (14\%) and neck (12\%) regions ${ }^{10} . \mathrm{In}$ another study conducted by Bork et al. on 928 physiotherapists, anatomical regions where musculoskeletal system problems occured most frequently were waist (45\%), hand / wrist $(29.6 \%)$, back $(28.7 \%)$ and neck regions $(24.7 \%)^{11}$.In the study conducted by Al-Eisave et al., the MSP in physiotherapists from Egypt and Saudi Arabia were evaluated.The neck (25\%) and waist (23.4\%) problems were observed most frequently in Egyptian physiotherapists.Problems in the waist (33\%) and neck (29\%) regionswere observed most frequently in Saudi therapists ${ }^{12}$. These studies are in parallel with our study in terms of the regions where the musculoskeletal systemproblems occur most frequently.

In the study conducted by Alrowayeh et al. on physiotherapists working in Kuwait, the prevalence of musculoskeletal system problems was found to be $47.6 \%$ in one year.The most common problems werein the low back (32\%), then neck (20\%), back (19\%), shoulder (13\%), wrist (11\%), knee (11\%), foot / ankle (6\%), elbow (4\%) and hip regions $(3 \%)$. It was found that there was relationship between low back, neck, shoulder pain and gender,and relationship between low back pain and age.At the same time, no relationship was found between these musculoskeletal problems and working hours, working areas, and exercise ${ }^{13}$.In our study, when the musculoskeletal problems occured in the last year were examined, it was found that there was no significant relationship between these problems and age and working year.In addition, shoulder pain was significantly higher in women and foot / ankle pain was significantly higher in men.As BMI increased, low back pain was found to be significantly higher. It 
was observed that there was a significant increase in the elbow problem depending on the number of working days per week and the increase of daily working hours.Knee and neck problems were found to be significantly less in physiotherapists who do exercise.

In the study of Adegoke et al. on Nigerian physiotherapists, musculoskeletal problems in the last 12 months were found to be $91.3 \%$.Low back $(69.8 \%)$ and neck pain were observed most frequently $(34.1 \%) .83 .5 \%$ of the participants stated that the most important factor in the formation of musculoskeletal problems is the work ${ }^{14}$.In our study, $83.8 \%$ of the participants think that the musculoskeletal system problems are workrelated.The study conducted by Adegoke et al. supports our work in line with these results.

The number of female and male participants in our study is different, and this is one of the limitations of our study.Another limitation of the study is that the participants were questioned about whether they didexercise butthey were not questioned about the type of exercise. Another limitation of the study is the inadequacy in determining the study areas of the participants. In addition, while evaluating musculoskeletal problems in our study, risk factors of these problems were not determined.This situation can be regarded as one of the limitations of our study.

As a result, this study has shown that physiotherapists have very high rates of MSP and physiotherapists are thought to gain awareness in this regard.

\section{REFERENCES}

1. Özel E \&Çetik O. Mesleki görevlerin ergonomik analizinde kullanılan araçlar ve bir uygulama örneği. Dumlupınar UniversityInstitute of ScienceJournal. 2010;(22):41-56

2. Bozkurt S.Ö. Gazi Üniversitesi Diş Hekimliği Fakültesinde Çalışan Diş Hekimlerinde İşe Bağlı Kas İskelet Hastalıklarının Değerlendirilmesi. 2011, Gazi University, Faculty of Medicine, Dissertation, 101 pages, Ankara, (Prof. Dr. Nesrin Demirsoy).

3. Ngan K\& Drebit S\& Siow S\&Yu S\& Keen D\& Alamgir H. Risk andcauses of musculoskeletal injuries among health care workers. Occupational Medicine. 2010;60:389-394.

4. Kazemi S. Gazi Üniversitesi BESYO Öğrencileri ile Diğer Fakültelerde Öğrenim Gören Öğrencilerin Kas İskelet Rahatsızlıkları Hakkında Farkındalıklarının Tanımlanması ve
REBA Yöntemi ile Ergonomik Risk Değerlendirmesi. 2016, Gazi University, Institute of Educational Sciences, Doctoral Dissertation, 99 pages, Ankara

5. Gürpınar B. Evaluation of work related musculoskeletal disorders and ergonomic awarness among physiotherapists, 2010, Dokuz Eylül University, Institute of Medical Sciences, Master's thesis, 67 pages, İzmir

6. Ağbaş N. KTÜ Farabi hastanesi büro çalışanlarının iş ortamına antropometrik uygunluğunun ve mevcut kas iskelet şikayetlerinin çalışma ortamıyla ilişkisinin araştırılması, 2008, Karadeniz TechnicalUniversity, Institute of Medical Sciences, Master's thesis, 69 pages, Trabzon

7. Diraçoğlu D. Sağlık personelinde kas-iskelet sistemi ağrıları. Türkiye Klinikleri JournalMedicineScience. 2006;26:132-139

8. Nordin N.A.M\& Leonard J.H\& Thye C.N. Work- related injuries among physiotherapists in public hospitals- a southeast Asian picture. Clinical science 2011;66(3):373-378

9. Tekeli H. Farklı alanlarda çalışan fizyoterapistlerde mesleğe bağli kas iskelet sistemine ait problemlerin değerlendirilmesi. 2009, Hacettepe University, Institute of Medical Sciences, Master's thesis, 93 pages, Ankara

10. Salık Y\& Özcan A. Work- related musculoskeletal disorders: A survey of physical therapists in Izmir-Turkey, BMC Musculoskeletal Disorders, 2004;5(27):1-7.

11. Bork E.B\&Cook T.M\& Rosecrance J.C\& Engelhardt K.A\& Thomason J.M\& Wouford I.J\& Worley R.K. Workrelatedmusculoskeletaldisordersamongphysical therapists. PhysicalTherapy. 1996;76(8):827835

12. Al-Eisa E \& Buragadda S\&Shaheen A.A.M\& Ibrahim A\&Melam G.R. Work related musculoskeletal disorders: Causes, prevalence and response among Egyptian and Saudi physical therapists. Middle- East Journal of Scientific Research. 2012; 12(4):523-529

13. Alrowayeh N.H\& Alshatti T.A\&Aljadi S.H\& Fares M\& Alshamire M.M\& Alwazan S.S. Prevalance, characteristicsandimpacts of workrelated musculoskeletal disorders: a survey among physicaltherapists in the state of Kuwait, BMC Musculoskeletal Disorders. 2010;11(116):2-11

14. Adegoke O.A.B\& Akodu K.A\& Oyeyemi C.A. Work- related musculoskeletal disorders among Nigerian physiotherapists. BMC MusculoskeletalDisorders 2008;9(112):1-9 